\title{
Examples of modernization of historical housing estates in the outskirts of Wroclaw - opportunities and threats
}

\author{
Alena Kononowicz \\ Department of Architecture and Urban Planning, Faculty of Engineering, Architecture and Environmental \\ Engineering, University of Zielona Góra, e-mail: a.kononowicz@aiu.uz.zgora.pl
}

\begin{abstract}
Recent decades have seen increased housing development activities in the outskirt housing estates of Wrocław, apparently driven by a trend of city dwellers escaping from the city somewhere "closer to nature". This applies also to Brochów and Psie Pole, former independent small towns with characteristic spatial arrangement. Once absorbed by Wrocław, these housing estates were subjected to on-going expansion whose size exceeded many times their historical core area. Restoration of the historical centre of Psie Pole undertaken by the City in 2009 has produced controversial results. The modernised old Marketplace has become a dead space in spite of renovated buildings and modern spatial development of the square. Along with the market stalls at the former bus terminal the people disappeared, too. Commercial traffic was moved to the rear of one of the frontages, a so-called "shopping arcade", in the vicinity of trash bins; whilst the benches in the renovated Marketplace are most frequently occupied by homeless people. Modernisation activities at the historical centre include: restoration, reconstruction or demolition of old buildings, construction of infill buildings, that often fail to harmonise with their surroundings.

Effects of the modernisation works carried out at the historical housing estate for railway employees in Brochów, where, for example, only halves of the semi-detached multifamily houses were refurbished; confirm the necessity to adopt a comprehensive approach to the renovation process. Elsewhere, thermal retrofitting with polystyrene left the facades of the buildings deformed and their original character was permanently lost.
\end{abstract}

Keywords: Modernisation, historical housing estates, Wrocław.

\section{Introduction}

Modernisation of historical housing estates in order to raise the standards of living and to improve the quality of life of the residents is complicated, but indispensible. Namely, it touches historical elements accumulated in the enclaves of characteristic, unique features that originate from the historical tradition of the site [1]. Often intensive expansion to the outside of the historical urban layout can cause new problems. In this way, new, large and stylistically different building enclaves come to live, and because of their scale and character they dominate the historical core area of the urban development plan. It should, however, be noted that new building enclaves have their own character and are also subject to change over time. In the future, they also may become the witness of the history that needs protection and maybe even restoration. Modernization of a housing estate doesn't only require adjusting its historical core to current requirements and needs of the residents, but also extracting and underlining its individual character in relation to both the urban layout as a whole and its separate elements. Historical housing estate should be always analysed in the context of 
surrounding area in the process of development. All modernization activities in historical city centre require caution and particular attention.

This article will present the problems of modernization of Wrocław's historical housing estate of Psie Pole and the architecture of houses of railway employees in Brochów.

\section{Overview of the history of the transformation of Psie Pole with respect to the modernization of the layout and architecture}

Former Psie Pole district had simple and non-complicated layout that has been preserved for many centuries since its foundation in $13^{\text {th }}$ century. Then, it was an open town without town walls and gates. The heart of it was main road - Bolesława Krzywoustego street extending in the south-east area into triangle-shaped Plac Rynkowy (Marketplace) - (today it is an extension of Krzywoustego street). The city centre was defined by two church buildings situated at the opposite ends of the main street. The first church of Saint Jacob and Saint Christopher was built at the beginning of $13^{\text {th }}$ century; the second - currently inexistent Protestant church was built only at the end of $18^{\text {th }}$ century and rebuilt at the end of $19^{\text {th }}$ century [2].

The first development plan of Psie Pole was made in 1910 in Wrocław's Technical Office of H. Meltzer and Th. Kreuz specialized in development plans of suburban communes. Designers have forecasted the city development to the south east of the railroad in the direction of Kiełczow and Zgorzelisko. One element stood out from the plan: the new street - ringroad with a stretch of green surrounding the old centre by a wide turn, following the current day Zielna and Mirkowska streets. Besides modern development plan of the town, the designers were willing to protect its historical centre by moving traffic to the ringroad. We can clearly see the influence of the popular at that time views of Camill Sitte. It is particularly reflected in the will to protect the historical part of the town, as well as in aesthetic appeal of the new development plan [3], [4]. The outbreak of the First World War jeopardised its implementation.

The concept of the ringroad returned in 1925 with the draft development plan of Psie Pole made in City Development Office within the framework of the first General Development Plan, which provided the grounds for extension of Wrocław's borders [5]. The new development plan of the housing estate signed by F. Behrendt included two ringroads: the first - "internal", which was to be used mainly by the residents, following the same route as the one in Meltzer and Kreuz development plan, and the second - "external", wider trunk road taking much more area, which was supposed to enable fast and unobstructed drive from Wrocław to industrial areas, which were to be built in north-east part of the town. Behrendt's development plan kept almost untouched the picturesque course of the main old town street of Psie Pole emphasised by the brackets of two church buildings. Low-rise buildings in the actual Unwin's style of garden districts formed the surface of the new housing estate. This development plan has never been implemented. In 1928, Psie Pole together with over twenty other suburban communes was incorporated into Wrocław becoming peripheral housing estate of the big city.

During the Second World War, Rheinmetall-Borsig enterprise opened a military factory in the district (later it became Kombinat PZL-Hydral - and now Wrocław Business Park 3 ); therefore, the housing estate for its employees was built at the street that is now called majora J. Piwnika-Ponurego street. The housing estate consists of several, two-storey blocks of flats, covered with a high gable roof. It has survived until these days in good shape and it constitutes very prominent enclave in the layout of Psie Pole.

After the Second World War, the city planners have had very ambitious plans for Psie Pole, which had fantastic opportunity to develop thanks to the industry located in the district. 
Urban character of the town was supposed to change completely. In 1952, the development plan of Psie Pole was prepared in the socialist realist style of baroque, axial composition. New “workers' city" functioning like Nowa Huta in symbiosis with industry was supposed to be built in 1960. However, the project was never carried out.

In the next decades the transformations of Psie Pole were not successful, because the construction of multi-family block of flats without any prior idea how to join them with the historical part of the district was very unfortunate.

One of the most negative examples is the group of five-storey, large-panel prefabricated blocks of flats constructed in 70-ties and 80-ties of the $20^{\text {th }}$ century at Sycowska street at the back of historical tenement houses at Krzywoustego street. On the one hand, the blocks of flats and their surroundings give positive impression of good and aesthetic place of residence, while on the other hand they create impersonal, repetitive space without individuality, which might be a part of any housing estate in any Polish city.

Another rush linked with the development of the district was construction of housing estates at the west end of Psie Pole, in Zgorzelisko, near Litewska and Kiełczowska streets. From 1977 until the beginning of the 80-ties of the $20^{\text {th }}$ century, the big housing estate of 10- and 4-storey, large-panel prefabricated blocks of flats was erected. It was called the housing estate of Bolesława Krzywoustego (Osiedle Bolesława Krzywoustego). It has become the place of residence of the workers of Polar and WSK-Hydral plants, the residents of Wrocław resettled within the framework of so-called "demolition action", and also academic staff (employees of Wrocław Technical University and Wrocław University of Agriculture). In 1977, the parish Church of Saint Kazimierz Królewicz was erected. Another construction phase started in 2003: this time, it encompassed the areas located near historical town, in the vicinity of Litewska and Poleska streets. What is more, the housing estate was cut in two by wide and busy road leading out of town, which broke the territorial cohesion of Psie Pole and had negative consequences in terms of the layout of the district.

The new project of Nowolitewska street has brought new hope to improve the traffic situation of the residents of Psie Pole. Nowolitewska street on the extension of Litewska street was supposed be a section of ringroad relieving historical centre and was to join socalled Trasa Warszawska (Jana III Sobieskiego avenue - B. Krzywoustego street) with socalled Trasa Olimpijska (following Żmudzka street) - up to Kiełczowska street, Bierutowska street and to Zakrzów. In order to facilitate the access to planned sites in the old centre, the crossing that were joining the streets: Krzywoustego, Bora-Komorowskiego, Bierutowska, Kiełczowska and Nowogorlicka was rebuilt. Soon, however, it turned out that Psie Pole wouldn't get any ringroad, and that the plan of connecting road of Nowolitewska street was deleted from the development plan of the Municipal Council. Namely, the road was missing from the Long-Term Investment Plan of the city and this proposition turned out to be only general concept. Traffic of new Rycerskie housing estate between Zielna street and the line of planned Nowolitewska street has become really problematic [6].

The solution for the housing estate could be general urban plans resulting from wellplanned communication strategy, which will join Psie Pole with the city and try to save the rest of its architectural and urban individuality. It's necessary to identify the thing that activates the residents of the housing estate and then to let it dominate the area. It might be industrial plant, cultural institution or commercial area combined with the function of dormitory town.

The layout of Psie Pole district has no reinforcement of well-planned, complex zoning which combines functional, technical, hygienic, aesthetic aspects and the protection of historical monuments in the urban space. 


\subsection{Problems of modernisation of the historical centre}

Let's take a closer look at the problems regarding modernisation and revalorisation of the old centre. In 2009, the conclusion of the competition for the housing development of the devastated part of Bolesława Krzywoustego street was greeted with renewed hope. The competition was organized by Municipal Investment Management Board within the frameworks of the program of revitalization of the city of Wrocław. The project has foreseen restoration of the old tenant houses, making modern shopping arcade at the back of the tenant houses and building of cultural centre with library, auditorium and education facility. Modernisation and revalorisation works conducted in the centre of Psie Pole had controversial effects. Modernised old Marketplace at Krzywoustego street has become a dead space despite many restored tenant houses and modern, terraced layout of the square with the fountain, greenery, statues and benches (Fig. 1). The main things that have killed city life in the Marketplace, were moving of bus stops away from the square and closure of kiosks, which before were situated nearby, and above all directing all of the commercial traffic to the back of the tenants houses at Bolesława Krzywoustego street number 304-312 to so-called commercial arcade in the vicinity of the trash bins. Before that, the square was alive thanks to hustle and bustle of the residents, passengers changing bus, people making shopping, or chatting with neighbours. After renovation it has become the sterile museum for recreational walks. But who today has the time to walk, especially that despite the fact that there is no car traffic, buses still pass through the square, and the homeless occupy the benches. The location of commercial mall at the back of the tenant houses is also not really fortunate (Fig. 2). The residents can't organize their private space for relaxation by their apartments. It is too noisy for such area.

The results of modernisation of historical centre of Psie Pole generate ambivalent attitudes. Without a doubt, several tenant houses were nicely restored, but some of them were demolished and the others are still in horrible shape, without windows or with shabby, dirty façade. There are also many negative examples of both restorations without taking into account cultural context and new buildings that don't correspond with the surroundings, most often oversized. For instance, the building of cultural centre at Krzywoustego street at the place of the former "Fama" cinema turned into furniture shop, is interesting because of its architectural form and colours, but on the other hand it emanates its stylistic dissimilarity and doesn't fit well with the surroundings. The question how to modernise historical space to let it live and not change it into the museum is still open.
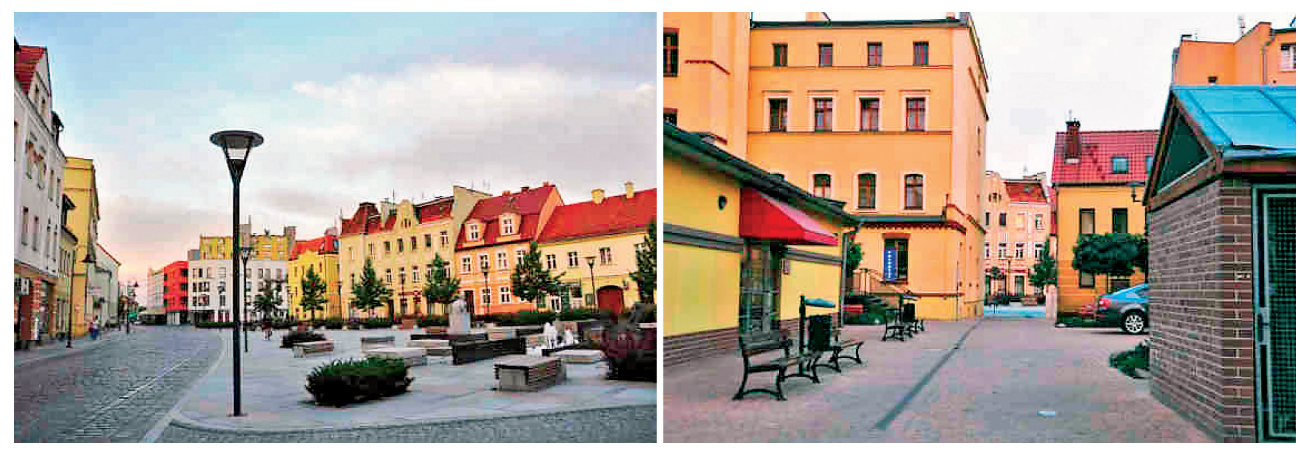

Fig. 1. Historical Market Square of Psie Pole after modernisation (on the left), (Pic. the author, 2016)

Fig. 2. Commercial arcade at the back of the tenant houses (on the right), (Pic. the author, 2016) 


\section{The examples of modernisation of historical architecture in Brochów}

Brochów housing estate, incorporated into Wrocław in 1951, is known for the versatility and complexity of its layout. The independence of the former town was based on the development of railway. One of the most interesting enclaves of the modern district is "Kolonia" -3-and 4-storey houses of railway workers built between 1896 and 1915. Most of the block of flats in "Kolonia" are semi-detached, 3-storey, brick, plastered houses with forth floor on side buttresses, designated for 24 to 28 families. Despite the fact that the halves of the houses constitute architecturally homogenous form, they function separately. They have separate entrances in the gable elevations. The buildings are seemingly unified, but the more thorough analysis shows that they differ by the disposition of the plan, location of staircases, layout of load-bearing walls and the numbers of floors. The form of "Kolonia" buildings is characteristic to housing estates made for workers of nearby factory, which is emphasized with its repetitiveness. The designer tried to give the building an artistic touch by diversifying of the façade with colour and structure of materials. Characteristic, decoration motive was timber-framing construction of the attics exposed on the façade and wooden finishing of the tops. Red of brick cornices, window and door bands contrasted with ochre and grey of plasters. Sidewalls were covered with geometric, two-coloured applications from fine and course plaster [7].

Nowadays the buildings don't belong to the railway anymore, and the residents of the apartments connected by one staircase create housing communities. Parts of historical buildings are subject to thermal retrofitting without coordination of this action with other communities. It means that half of the building is renovated, while second half might be untouched, still remaining in very bad shape (Fig. 3). The choice of colours and the doubtful preservation of the former plaster applications on the gable walls of the buildings are also debatable (Fig. 4).

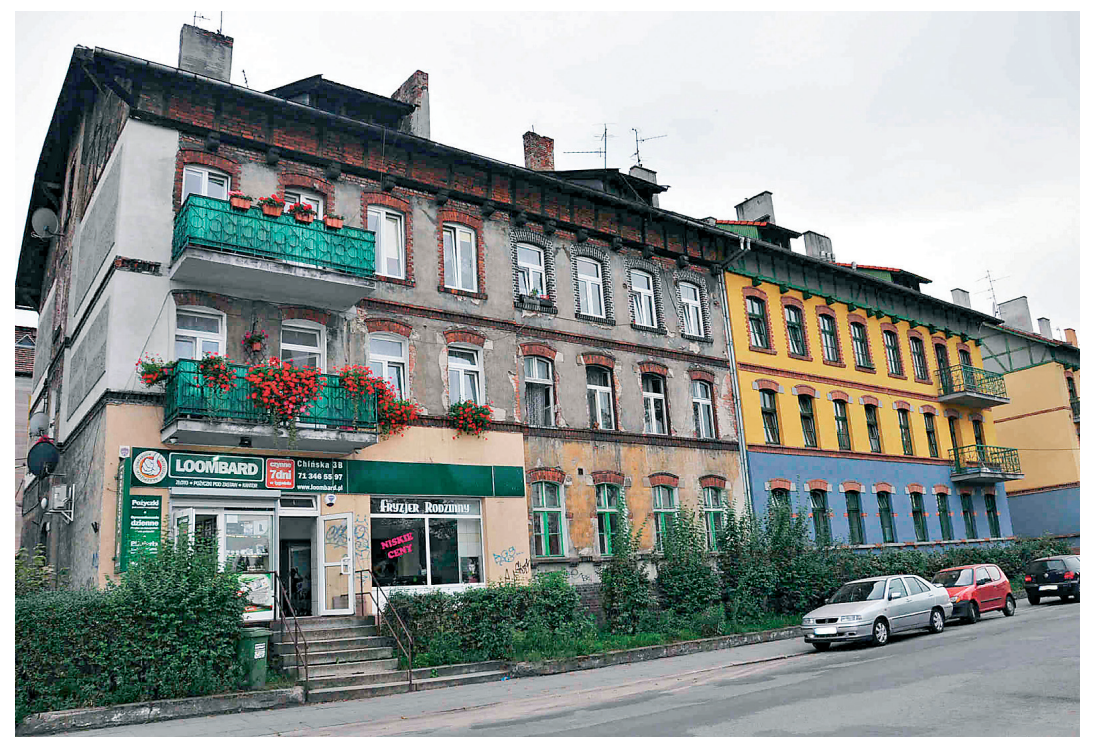

Fig. 3. Multi-family semi-detached house of the former "Kolonia" housing estate for the employees of the railway at Chińska street no. 4 - the example of incorrect half-modernization, (Pic. the author, 2016) 


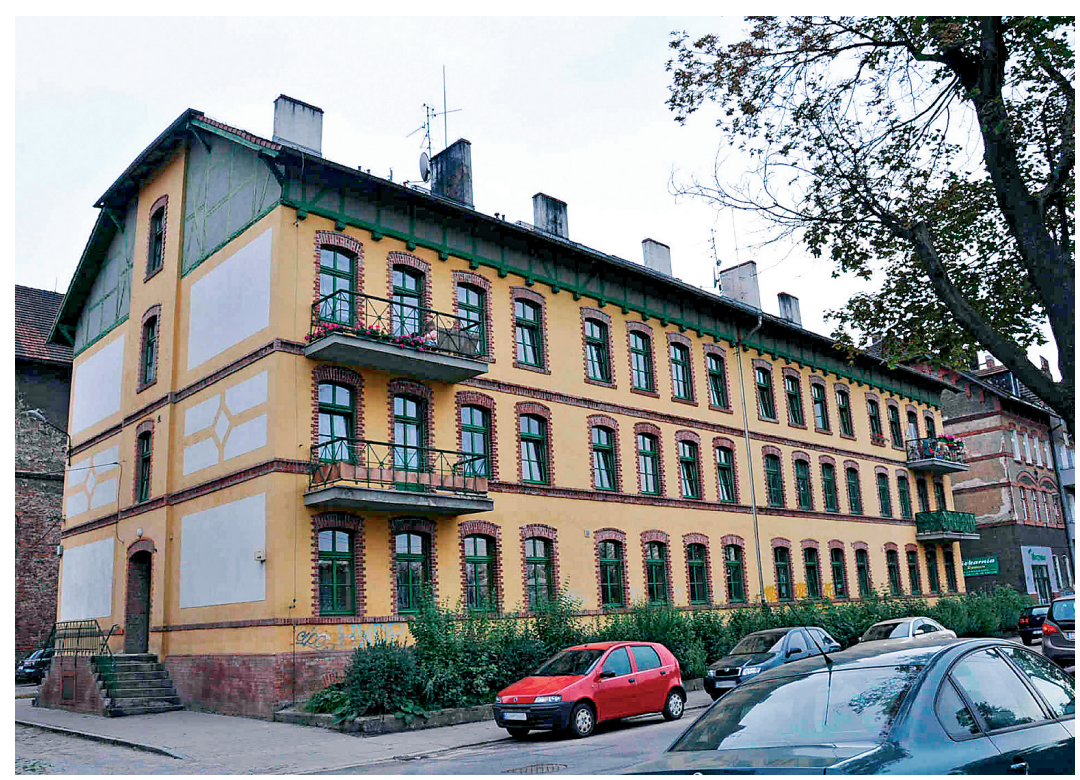

Fig. 4. Multi-family semi-detached house of the former "Kolonia" housing estate for the employees of the railway at Chińska street no. 14 - the example of acceptable modernization, (Pic. the author, 2016)

\section{Summary}

The process of modernisation of the historical housing estates as well as their architecture is the difficult task that requires from both designer and contractor not only specialist knowledge and due diligence, but above all a sense of aesthetics. Modernisation of the housing estate is not only an adaptation of the historical centre to the modern requirements, but also extension of the housing estate outside of the former urban layout [8]. In this way, stylistically different, voluminous development compounds are constructed in the urban space dominating and degrading the historical core by its scale and character. Hence, all modernisation activities in the historical centre require particular attention. It is essential to undertake complex approach, which takes into account cultural context to restore spatial structure as well as revalorisation of the individual buildings. It is indispensable to keep characteristic features of the architecture or public space including their scale and proportions [9][10].

\section{References}

[1] Kononowicz W., Sukienniczak J. Revalorization problems of the down-town areas on the example of Zielona Góra. Civil and Environmental Engineering Reports 23(4) (2016) 79-88.

[2] Kononowicz A. Wrocławskie Psie Pole na kartach historii i w opinii swoich mieszkańców. Architektus 1(19) (2006) 85-97.

[3] Sitte C. Der Städtebau nach seinen künstlerischen Grundsätzen. Wien 1889.

[4] Kłosek-Kozłowska D. Dziedzictwo miast. Ochrona i rozwój. PAN, Warszawska Drukarnia Naukowa, Warszawa 2013. 
[5] Kononowicz W. Pierwszy plan generalny Wrocławia (1924) i początki kompleksowego projektowania urbanistycznego. Architektura Wrocławia, volume 2. Urbanistyka do roku 1945, red. J. Rozpędowski, Wrocław 1995, p. 301-338.

[6] Józefiak B. Psie Pole bez obwodnicy. Wrocław rezygnuje z Nowolitewskiej. Polska Gazeta Wroclaw 23.12.2012.

[7] Kononowicz A. Urbanistyka i architektura kolejarskiego osiedla Brochów we Wrocławiu. Obiekty kolejowe. Układy przestrzenne, architektura, elementy techniki, red. W. Czarnecki, M. Proniewski, Białystok, 2005. p. 295-305.

[8] Rymaszewski B. Polska ochrona zabytków. Wydawnictwo Naukowe SCHOLAR, Warszawa 2005.

[9] Rymaszewski B. O przetrwanie dawnych miast. Wydawnictwo Arkady, Warszawa 1984.

[10] Chmielewski J.M. Teoria Urbanistyki w projektowaniu i planowaniu miast. Oficyna Wydawnicza Politechniki Warszawskiej, Warszawa 2001. 